\title{
Atlas of specialized maps of Central-Kyzylkum uranium ore province
}

\author{
1:500000
}

The Atlas is prepared for one of the world's largest uranium ore provinces covering an area of 180,000 $\mathrm{km}^{2}$. This set of specialized maps shows some regularities of the occrrence of exogenous epigenetic uranium mineralization, which presents the main commercial type of uranium deposits connected with stratal oxidation zones (sandstone type in IAEA's classification) developed in Central-Kyzylkum uranium ore province. The Atlas presents a result of many-years' joint investigations by production-geological and scientific organizations of Uzbekistan and Russia. Theory of exogenous stratal-infiltration mineralization and methods of searching for uranium deposits poorly manifested on the surface, successfully worked out in the end of 1950s, brought about the discovery of 25 commercial uranium deposits of this type after 40 years' study of the Central-Kyzylkum uranium ore province. 11 of these deposits are large and unique., and 12 of them were turned over to production organizations and are now successfully under operation using the most economic technique-in situ leach (ISL) from uranium ore-hosting rocks.

The Atlas consists of 11 lithologic-paleogeographical maps (from Aptian to Late Eocene), 10 lithologicgeochemical maps with data on uranium mineralization abundance (from Lower Aptian to Upper Eocene), a map of neotectonic structures, two hydrogeological and two radio-hydrogeological maps of Upper Cretaceous, Paleozoic and Upper-Pliocene-Quaternary aquifers. The maps of helium, hydrogen, methane and carbon dioxide gas halos present results of ground gas exhalation geochemical studies. A specialized geological map with data on uranium abundance and lithologic-geochemical logs for uranium ore regions is given as summarized materials. Presence of ore-forming infiltration process in different stratigraphic intervals on the territory of Central-Kyzylkum uranium ore province defines the presence of respective lithologic-paleogeographical and lithologic-geochemical maps in the Atlas.

The lithologic-paleogeographical maps of the Atlas allow to identify surficial settings favorable for epigenetic mineralization and, respectively, favorable for mineralization formations occurred under these settings. The horizon-to-horizon lithologic-geochemical maps reflect spatial distribution of ore-forming stratal oxidation zones within thick productive measures of the sedimentary cover and allow predicting other areas of infiltration mineralization.

The hydrogeological and radiohydrogeological maps characterize distribution of underground waters with different mineralization, ionic-salt composition, temperature, and uranium contents. The summarized specialized geological map generalizes main geological prerequisites defining formation and distribution of infiltration uranium mineralization and reflects vista of uranium abundance in Central-Kyzylkum province.

The Atlas comprises a set of various geological data interesting for geologists of different specialization, and can be used as a basis for target selection and search for deposits of uranium and accompanying element (selenium, molybdenum, scandium, vanadium and others) in areas with similar geology. The Atlas also can be used as a visual aid in training geologists in uranium.

Totally the Atlas comprises 30 maps. Explanatory note is on the back of the maps, introductory and conclusion articles are presented as separate sheets. The Atlas can be made in boards or as a roll by request of the subscriber.

For the price of the Atlas please contract:

E-mail: redhill@globalnet.uz., gicenter@online.ru

Address: 7a Navoi St., Tashkent, 700000, Uzbekistan. Att.: Korsakov Yu.F.

Fax: $(+998-71) 413033$ 